\title{
THE CONTRIBUTION MADE BY T.E. LAWRENCE TO THE THEORY OF REVOLUTIONARY WARFARE
}

Maj. G.K.B. Barron*

Introduction

Lawrence was basically an academic thrown into the hurly-burly of leading an Arab revolt against Turkish domination. It could be said that the war in the Middle East was a sideshow of the First World War and Lawrence's part was a '... sideshow to the sideshow'1) Why then has Lawrence been remembered when greater military men have been forgotten? The romanticism of his exploits are surely the reason, and yet the fact that he is the first modern theorist and possibly the "father" of modern revolutionary warfare, tends to be forgotten.

\section{A short resume of T.E. Lawrence's early life and his role in World War I}

T.E. Lawrence was born in Tremadoc in North Wales in 1888, the illigitimate son of Thomas Chapman (later Lawrence). A devout reader he won a scholarship to Oxford High School and later also to Oxford University where he specialised in Archeology and Military History. The former study field was the reason for his travels to Arabia where to an extent he learnt the local language and customs. ${ }^{2}$ )

By the end of 1914 his Arabian experience had led to his appointment as a lieutenant in the intelligence section in Cairo. ${ }^{3)}$ The Arabs in the Hejezarea rose unsuccessfully against their Turkish overlords in June 1916. ${ }^{4)}$ In 1917 Lawrence was given a lone hand in the British leadership of the Arabs in revolt against the Turks. This revolt eventually culminated in a descent upon Aqaba, clearing all resistance to British communications in Sinai. These victories left an Arab threat to the flank of the main Turkish forces which were in opposition to the British. A significant part was played by Lawrence's Arab force using irregular methods and it is claimed that the contributions significantly assisted the British, under Allenby, to victory in Palestine. ${ }^{5)}$

\section{Lawrence's delineation of the aim and nature of the war in which he personally was involved}

The textbooks, claimed Lawrence, tended to give the aim of war as ' ... the destruction of the armed forces of the enemy by one process battle'. ${ }^{6)}$ Foch had called his war 'Absolute'; where the incompatible philosophies of two nations were put to the test of force. ${ }^{7)}$
Lawrence wondered if the 'absolute' was not possibly just a variety of warfare. ${ }^{8)}$ The Arabs certainly in their style and method could not defeat the Turks by armed confrontation alone. The tenet that 'Victory could only be purchased by blood'9) couldn't be fulfilled. Lawrence reviewing the aim of the Arabs decided that it was actually the extrusion of the Turks from the Arabic-speaking lands. ${ }^{10)}$ 'If they would go quietly the war would end. ${ }^{111)}$ It also occurred to Lawrence that the Arabs were in command of $99 \%$ of the Hejaz. Why then not let the Turks keep the other $1 \%$ until the futility of the exercise was realised? Was the war already not being won? ${ }^{12)}$

An interesting factor which is considered here is the willingness or even 'daring' of Lawrence to break from the traditional military thinking of a physical conflict being the only decisive factor in war. This, especially at a time when battle was being pursued rigorously on many fronts during World War I. Although he had read widely in the military field, his willingness to break from tradition, could to an extent be accounted for by his lack of a prior career in the military. His penchant for an academic approach could account for the assimilation of factors, other than purely military ones, into his reckoning.

\section{Lawrence's elements of analysis of the situation}

It is true that the Revolutionary Warfare tactics had been utilised in history before the First World War, but, because they were the only possibly executive alternatives in certain circumstances. 'It was not until the Twentieth Century and Lawrence that an element of systematic strategic planning was added. ${ }^{133}$ His philosophy by which 
a military inferior can defeat 'a superior conventional antagonist' ${ }^{14)}$ is surely the essence of his contribution. The analysing elements which he applied to the situation and which then led to the strategy and tactics which he followed are threefold.

\section{ELEMENT 1: Algebraic}

The essential idea of this element was that the invariables and known variables of the war were measured to arrive at specific conclusions. ${ }^{15)}$ Things such as inorganic factors like railways, hills, climates and other known factors such as men in mass, (not as individuals), space and time and artificial aids were taken into account. In short, anything that was formulable. ${ }^{16)}$

Lawrence calculated that the area to be won was about 140000 square miles. If the defence were to be physically sound a trench line across the area would be necessary. However, he reasoned that if the Arabs were intangible, like a 'vapour', then to contain this sedition everywhere a fortified post of 20 men would be necessary every 4 square miles. This would require 600000 men. 100000 were available to the Turks. ${ }^{17)}$

\section{ELEMENT 2: Biological (Bionomics)}

This was construed to be the relationship between the organism and its environment. ${ }^{18)}$ If this was considered to be the humanity in battle, the material could not be excluded.

It is the Commander's task to relate the various factors to the circumstances. This could not be expressed purely formularly because individuals were involved and there must be some element of the 'feel' of the Commander in any decision. ${ }^{19)}$ Lawrence expressed it thus: 'Nine tenths of tactics are certain and taught in books; but the irrational tenth is like the kingfisher flashing across the pool, and that is the test of generals. ${ }^{20)}$

Drawn from this bionomical element were two main factors which had to be taken into account. As far as the Turks were concerned, materials were scarce and manpower not so. Therefore concentration should be on the enemy's materials. On the Arab side, the men were more individuals than units, with the implication that an '... individual death like a pebble dropped in water, might make but a brief hole; yet rings of sorrow widened out therefrom'21)

\section{ELEMENT 3: Psychological}

a. The 'ethical in war' or the diathetic. This is the adjustment of spirit of the crowd and individual to be able to exploit it in action towards a required objective. ${ }^{22)}$ Not only must the mind of the own combatants be arranged but those of the enemy, the minds of the rest of the own people, the enemy nation waiting and the neutrals watching and so on '... circle beyond circle ${ }^{\prime 23)}$

The shortcomings in the material sense had to be balanced by this, the metaphysical. Lawrence claimed that the ' ... printing press is the greatest weapon in the armoury of the modern commander. ${ }^{24)}$ The contest to Lawrence was not physical but moral and battles were not always necessary. ${ }^{25)}$

A victory would be won in Arabia when the civilians in each province had been prepared to die for the Lawrence - defined ideal of freedom. The presence or absence of the enemy would then not be an important factor. ${ }^{26)}$ The struggleowas one for independence in which politics had become a primary weapon. $^{27)}$

The three elements of analysis which Lawrence formulated: the tangible assets and calculable operating sphere; the quality of the quantity in the aforementioned and the commander's evaluation thereof; and the psychologically-influencing factors; were used by Lawrence in his review of the Arab situation. These led him to the conclusion that an indirect approach was necessary. These elements are still very valid in the contemporary world in the analysis of any confrontation situation. If they are correctly applied, the evaluation should lead to the best means and method of action. It is necessary to elucidate again that it was a feat for this strategic analytical model to emerge from a person of relatively low rank during a 'very conventional' period of military history.

\section{Some of T.E. Lawrence's individual Treatises on Revolutionary Warfare, delineated}

In this section some of Lawrence's thoughts (and actions) have been extracted and grouped into categories for correlation with later Revolutionary Warfare thoughts and actions. 


\section{Motivation Cause}

Lawrence claims that a doctrine is essential to the conduct of revolutionary warfare. ${ }^{28)} \mathrm{A}$ 'will' must be created. ${ }^{29)}$

The Sherifs reason for participation in the war was basically a nationalistic one. Their nationalism meant an Arabic-speaking government which would let the people live in peace. ${ }^{30}$ Lawrence was the first to tie revolutionary warfare directly to political aspirations, wherein the guerrillas involved had a military and political function. ${ }^{31)}$

This undoubtedly is one of the most important factors in Revolutionary Warfare for it supplies the reason for the individual protagonist to take up the yoke of the struggle. This cause ties in closely with the diathetic element of analysis. The importance of propaganda in this facet is illustrated by Lawrence's comment on the printing press.

\section{The Leader}

Lawrence pleaded for a greater seriousness in the study of history and the military art, claiming that with 2000 years behind the militarists there is '... no excuse when fighting for not fighting

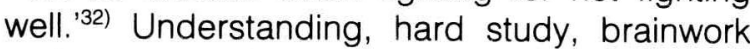
and concentration were all qualities which he deemed extremely necessary. ${ }^{33)}$ Before decisions were taken all relevant and sometimes even irrelevant factors had to be studied. ${ }^{34)}$

His leadership and the quality thereof comes to the fore especially in his knowledge of, and sensible manner of handling of the people with whom he had to work. His 'Twenty-Seven Articles' of handling Arabs are to be found in LiddelHarts biography of Lawrence. ${ }^{35)}$ Liddel-Hart claimed that he had never met a general who had read as widely as Lawrence. ${ }^{36)}$ So deeply was he immersed in his leadership that when an argument resulted in one of his men killing another, Lawrence himself executed the killer on the spot to prevent a possible blood feud. ${ }^{37)}$

Training, efficiency and dedication are mirrored as requisites by Lawrence's actions and theories on leadership. A striking example of these three qualities is possibly found in his compilation of the 'Twenty-Seven Articles.' The insight and precise evaluation shown in these serve as an example and could be (sufficiently amended) applied to the handling of any foreign peoples.
Lawrence's exploits and evaluation of the situation in which he found himself speak volumes about his leadership and therefore also make him an excellent tutor

\section{Time}

Lawrence spoke of the 'protracted war.'38) Time is a requisite for the revolutionary for the application of his doctrine and thereby the strengthening of his forces. ${ }^{39)}$ The follow on logically from the protracted war is the war of attrition whereby battles were ' ... an imposition,' ' ... a mistake' for all that was necessarily gained was the ammunition which the enemy fired off. ${ }^{40)}$

The Turks at Medina were left alone while the Arabs selectively destroyed their communications till as Lawrence said ' ... peace or Doomsday saved them the futility of clinging to our window pane.'41) The economy of life was deemed more precious than money or time. ${ }^{42)}$

It seems to be apparent in some measure that Lawrence would have been prepared to continue his unconventional campaign until he could either build up a large enough force to conventionally defeat the Turks, or until the Turks decided that they were not achieving much by staying.

\section{Support of the Population}

This factor, Lawrence claimed was an essential. A rebellion could be successfully executed if only $2 \%$ of the population served in the striking force. The other $98 \%$ however had to be passively sympathetic, that is, they did not give away the movements of the others. ${ }^{43}$ )

Apart from his popular nationalistic cause, gold was also used to gain assistance. ${ }^{44)} \mathrm{His}$ knowledge of the population assisted him in this respect as well. He could not mix or combine different tribes due to dislike and mistrust and he would not even allow one tribe to operate in the territory of another. ${ }^{45)}$

Lawrence fully realised the importance of the support of the population and once again by his actions and theory it is obvious that he was out to solicit this support. It is significant that in warfare today this aspect is possibly the most important linked with a popular cause.

\section{The Struggle}

The principles established in this aspect by Law- 
rence were very much concentrated on conditions experienced by him but the application may be very much wider.

Discipline. Too deep or automatic a discipline meant a deliberate sacrifice of capability in reducing the uncertain human element. ${ }^{46)}$ The basis for discipline had to be the self, and the source of the discipline, the enthusiasm and support for the cause. ${ }^{47)}$

Range is more to Strategy than Force. The methods used by Lawrence were flexible. A standard description could be ' ... the smallest force in the quickest time at the farthest place. ${ }^{48)}$ Hit and run tactics especially at logistics supply, ('The invention of bullybeef had profited us more than the invention of gunpowder. ${ }^{149}$ ) had the dual purpose of hitting at the enemy as well as denying him a target to strike back at. An integral part of these operations was intelligence (for perfect planning and execution), and mobility. ${ }^{50)}$ Lawrence claimed that the active revolutionary must possess the qualities of '.. speed, endurance, ubiquity and independence of arteries of supply. ${ }^{51)}$ Technical equipment was necessary to hit at the enemy communications. ${ }^{52)}$

Once again the emergence of ideas and practices such as these in this period of time were daring. These views of Lawrence on his war are not limited by any means to his war and have a far wider application.

\section{Outside Support}

Although this factor is not specifically mentioned by Lawrence, his very use and dependence on support, namely that of Britain, propagated this dictum. The gold, occasional aircraft and armoured car support, and especially the technical materials supplied, and political support were to an extent the lifeblood of his movement, (although they were improved by good utilisation).

\section{Unassailable Bases}

One of the factors which Lawrence claimed should lead to inevitable success in the revolutionary struggle is that of an '... unassailable base, something guarded not only from attack but from fear of attack. ${ }^{53)} \mathrm{He}$ further allowed that this need not necessarily be only physical but also in the '... minds of men converted to its creed. ${ }^{154)}$ In the physical sense though, the vast, empty desert did furnish ideal base areas. ${ }^{55)}$ Once again Lawrence had in this factor grasped one of the basic factors playing a large part in revolutionary warfare today.

\section{Comparison of Lawrence's Theory and the contemporary practice of Revolutionary Warfare}

General Fraser in his study of the revolutionary wars since World War II until the late 1960's claims that although no two of these wars have been identical there have been certain common factors which he has extracted as:
A popular cause.
Trained, efficient and dedicated lead- ership.
Time to develop.
Support of the population.
A population with a need, a determina- tion and an ability to wage a prolonged struggle.
Outside support.
A firm base or sanctuary. ${ }^{56)}$

Someone in their own midst could have been the "father" of modern revolutionary warfare.

It has been indicated that perhaps the work of some of these Communist protagonists was not entirely original but that some of their theory was adopted from Lawrence. In 1936 one of the Communist Chinese Generals - Lu Chong Ts'oa, was found to have a Chinese translation of 'Seven Pillars of Wisdom' and admitted that he and other Red commanders considered the book one of the standard reference works on strategy. ${ }^{57)}$ It is also variously claimed that his work was more appreciated "... in Russia and China'58) ' . . . by the Communists' ${ }^{\text {'59) }}$ than by his own people. General Giap was once observed entering a conference venue with 'Seven Pillars of Wisdom' under his arm, ${ }^{60}$ ) and Mrazek even goes as far as to claim that ' . . for more than 25 years he was discreetly plagiarised by Red China's boss Mao Tse-Tung and his cohorts. ${ }^{161)}$

If the latter statements are taken to be true then this considerably enhances his contribution although it may already be considered as substantial. The mere fact that principles formulated under desert conditions could be applied to revolutionary warfare in totally different conditions is a major commendation.

Liddel-Hart claims that: 'He is seen to be more 
than a guerrilla genius - rather does he appear a strategist of genius who had the vision to anticipate the guerrilla trend of civilised warfare that arises from the growing dependence of nations on industrial resources. ${ }^{162)}$

\section{Conclusion}

Lawrence was thrust into his task in World War I as Arab commander because of his background which included study in Arabia. Evaluating the forces at his disposal, he questioned the definition of war as always including battle and refused to accept that 'Absolute' war as defined by Foch, was the only type of warfare. The aim of his war was to extrude the Turks from Arabia and not necessarily defeat them in battle.

He developed and utilised three elements (Algebraic, Biological and Psychological) of analysis. These could be used to analyse any conflict. From the analysis of his own situation he decided that the best strategy to follow would be that of the indirect approach. From here he developed individual modes of thought or treatises to pursue his indirect approach strategy. An interesting comparison is then drawn between Lawrence's theory and factors extracted as being common factors in all revolutionary wars between the end of the Second World War and the late 1960's. This latter study, incidentally, having been done by General C.A. Fraser. The comparison of these factors shows a very close correlation, in other words Lawrence's theory is mirrored in latter-day action. This gives an indication of Lawrence's contribution to revolutionary warfare.

However, not much is heard of Lawrence as a protagonist of revolutionary warfare. It seems as if Westerners, especially, revere only the Communist revolutionaries Mao Tse-Tung, Giap and Guevara. It is indicated that Lawrence's theories could have been 'borrowed' in part by these gentlemen. If this is so, it increases the value of Lawrence's contribution.

In any case, the contribution made by Lawrence is considered to be substantial. The analysing elements and individual treatises, even though formulated in desert conditions and before 1918, are just as valid in any other conditions over 50 years later.

*Maj G.K.B. Barron of Ondangwa, SWA was awarded second prize for the above contribution to the Military Essay Competition of 1980

\section{Sources: Literature}

Asprey, R.B.: War in the Shadows (The Guerrilla in History). London, 1975. Blacker, I.R.: Behind the Lines (Twenty-eight Stories of Irregular Warfare). London, 1956.

Brent, P.: Great Lives - T.E. Lawrence. London, 1975.

Encyclopaedia Britannica X. London, 1955.

Encyclopaedia Britannica, Macropaedia, Vol 8. Chicago, 1973.

Encyclopaedia Britannica, Macropaedia, Vol 10. Chicago, 1973.

Fraser, C.A.: Revolutionay Wartare: Basic Principles of Counter Insurgency (being a Revision of Lessons Learnt from Past Revolutionary Wars) np, nd.

Gann, L.H.: Guerrillas in History. Stanford, 1972.

Grundy, K.W.: Ideology and Insurrection: The Theory of Guerrilla Warfare in Africa. San Francisco, 1967.

Heinl, R.D. (cd): Dictionary of Military and Naval Quotations. 2nd Printing, Annapolis, 1967.

Knightley, $\mathrm{P}$ and Simpson, C.: The Secret Lives of Lawrence of Arabia. London, 1961.

Lass, H.R.: Die Grondleggers van Rewolusionêre Oorlogvoering (Mao TseTung, Vo Nquyen Giap en Chè Guevara). Tweede Druk, Pretoria, 1976.

Lawrence, T.E.: Revolg in the Desert. London, 1927.

Lawrence, T.E.: Seven Pillars of Wisdom. Reprinting, London, 1963.

Levy, Y.B.: Guerrilla Warfare. Boulder, 1964.

Liddel-Hart, B.H.: History of the First World War. 4th Printing, London, 1976.

Liddel-Hart, B.H.: T.E. Lawrence (in Arabia and After). London, 1934.

Mrazek, J.: The Art of Winning Wars New York, 1968.

Osanka, F.M. (ed): Modern Guerrilla Warfare (Fighting Communist Guerrilla Movements, 1941-1961). New York, 1962.

Taylor, A.J.P. (ed): History of World War One. np, nd.

Thayer, C.W.: Guerrilla. London 1964.

\section{Periodical Publications}

The Army Quarterly and Defence Journal, Vol. 106, No. 1, January, 1976.

\section{Footnotes}

1. P. Knightley and C. Simpson: The Secret Lives of Lawrence of Arabia, p. 77.

2. A.J.P. Taylor: History of World War I, p 133

3. Encyclopaedia Britannica (Macropaedia) 10, p 785.

4. B.H. Liddel-Hart: History of the First World War, p 212.

5. Encyclopaedia Britannica (Macropaedia) 8, p 459.

6. I.R. Blacker: Behind the Lines (Twenty-eight stories of Irregular Warfare), p 122.

7. T.E. Lawrence: Seven Pillars of Wisdom, p 195.

8. B.H. Liddel-Hart: T.E. Lawrence (In Arabia and After), p 170.

9. T.E. Lawrence: op cit, $p 194$.

10. R.B. Asprey: War in the Shadows (The Guerrilla in History), p 285

11. T.E. Lawrence: op cit, p 196.

12. Encyclopaedia Britannica X, p 950A.

13. K.W. Grundy: Ideology and Insurrection: The Theory of Guerrilla Warfare in Africa, $p 4$.

14. J. Mrazek: The Art of Winning Wars, $p 126$.

15. R.B. Asprey: op cit, $p 286$.

16. T.E. Lawrence: op cit, $p 197$.

17. Encyclopaedia Britannica X, p 950A.

18. R.B. Asprey: op cit, $p 286$.

19. T.E. Lawrence: op cit, pp 198, 199.

20. Encyclopaedia Britannica X, p 950A

21. I.R. Blacker: op cit, $p 125$.

22. T.E. Lawrence: op cit, $p 200$.

23. The Army Quarterly and Defence Journal, Vol 106, No. 1, January 1976 (A Burton: Arranging the Minds of Men), $p 53$.

24. B.H. Liddel-Hart: op cit, $p 176$.

25. R.B. Asprey: op cit, $p 287$

26. Y.B. Levy: Guerrilla Warfare, $p 31$

27. H.R. Lass: Die Grondleggers van Revolusionêre Oorlogvoering (Mao Tse-Tung, Vo Nguyen Giap en Chè Guevara), p 69.

28. Encyclopaedia Britannica X, p $950 \mathrm{D}$.

29. The Army Quarterly ..., January 1976, $p 51$.

30. T.E. Lawrence: op cit, $p 103$.

31. H.R. Lass: op cit, $p 159$.

32. R.B. Asprey: op cit, p 293.

33. The Army Quarterly ..., January 1976, p 58.

34. B.H. Liddel-Hart: op cit, $p 447$. 
35. Ibid, $p 142$.

36. Ibid, $\mathrm{p} 446$.

37. P. Brent: Great Lives - T.E. Lawrence, p. 111.

38. J. Mrazek: Op cit, $p 139$.

39. Encyclopaedia Britannica X, p 950D.

40. B.H. Liddel-Hart: op cit, $p 177$.

41. T.E. Lawrence: Revolt in the Desert, p 96.

42. Loc cit.

43. L.H. Gann: Guerrillas in History, p 45.

44. The Army Quarterly ..., January 1976, $p 58$.

45. Encyclopaedia Britannica X, p 950C.

46. R.D. Heinl (ed): Dictionary of Military and Naval Quotations, $p 93$.

47. H.R. Lass: op cit, $p 66$.

48. R.D. Heinl: op cit, $p$ 101.

49. T.E. Lawrence: Seven Pillars of Wisdom, p 202.

50. R.B. Asprey: op cit, p 290.
51. Encyclopaedia Britannica X, p 950C.

52. T.E. Lawrence: op cit, $p 202$.

53. T.E. Lawrence: 00 cit, $p 202$.

54. Encyclopaedia Britannica X, p 950C

55. C.W. Thayer: Guerrilla, $p 114$.

56. C.A. Fraser: Revolutionary Wariare: Basic Principles of Counter Insurgency (Being a Revision of lessons learnt from past Revolutionary Wars), p 5 .

57. J. Mrazek: op cit, $p 128$

58. F.M. Osanka (ed): Modern Guerrilla Warfare (Fighting Communist Guerrilla Movements, 1941-1961), p 7.

59. H.R. Lass: op cit, p. 70.

60. The Army Quarterly ...., January 1976, p 52.

61. J. Mrazek: op cit, p 126

62. B.H. Liddel-Hart: op cit, p 438. 